\title{
Autosomal dominant retinitis pigmentosa with apparent incomplete penetrance: a clinical, electrophysiological, psychophysical, and molecular genetic study
}

\author{
A T Moore, F Fitzke, M Jay, G B Arden, C F Inglehearn, T J Keen, S S Bhattacharya, A C Bird
}

\begin{abstract}
Twenty five symptomatic individuals and six asymptomatic obligate gene carriers from four families with autosomal dominant retinitis pigmentosa (adRP) showing apparent incomplete penetrance have been studied. Symptomatic individuals from three families showed early onset of night blindness, non-recordable rod electroretinograms, and marked elevation of both rod and cone thresholds in all subjects tested. In the fourth family, there was more variation in the age of onset of night blindness and some symptomatic individuals showed well preserved rod and cone function in some retinal areas. All asymptomatic individuals tested had evidence of mild abnormalities of rod and cone function, indicating that these families show marked variation in expressivity rather than true non-penetrance of the adRP gene. No mutations of the rhodopsin or RDS genes were found in these families and the precise genetic mutation(s) remain to be identified.
\end{abstract}

(Brf Ophthalmol 1993; 77: 473-479)

Clinical and psychophysical studies in autosomal dominant retinitis pigmentosa (adRP) have suggested that there may be genetic heterogeneity within the disorder. ${ }^{1-5}$ This has been confirmed by the finding of mutations in the rhodopsin gene on chromosome $3^{67}$ and the retinal degeneration slow (RDS) gene on chromosome $6^{8-10}$ in some families with adRP. Some forms of adRP do not show linkage to or mutations of either the rhodopsin gene or the RDS gene and additional genetic mutations remain to be identified.

Most families, including those with known mutations, show complete penetrance of the adRP gene. In a few families incomplete penetrance is a notable feature ${ }^{11-15}$ and it has been suggested on the basis of the electroretinographic findings that this may be a distinct form of adRP. ${ }^{11} 12$

We have studied both symptomatic individuals and asymptomatic obligate gene carriers from four families showing apparent incomplete penetrance in order to characterise the pattern of retinal disease in affected family members and to investigate rod and cone function in those obligate gene carriers who remain asymptomatic in the fourth or fifth decade of life. We have also investigated whether any of the families show mutations of the rhodopsin or RDS genes, or linkage to chromosomes 3 or 6 .

\section{Patients and methods}

Twenty five symptomatic individuals (mean age 32 years; range 13-58 years) and six asymptomatic obligate gene carriers (mean age 46 years; range 39-60 years) from four families with apparent incomplete penetrance took part in the study. In each family there was transmission of the disease through at least three generations (Fig 1 ), and in three there was evidence of male to male transmission. In the fourth, although there was no male to male transmission, all the affected females had severe disease, suggesting autosomal dominant inheritance.

Each subject underwent a full clinical evaluation. A variety of investigations including an electroretinography (ERG), electro-oculography (EOG), Goldmann perimetry, and detailed dark adapted static perimetry were performed in the majority of subjects (subjects with advanced RP with extensive field loss did not undergo psychophysical testing). In addition, photopic flicker testing was performed on each of the six asymptomatic obligate gene carriers. Detailed Goldmann perimetry was performed on each eye using the IV $4 \mathrm{e}$ and I $4 \mathrm{e}$ targets. The ERG was

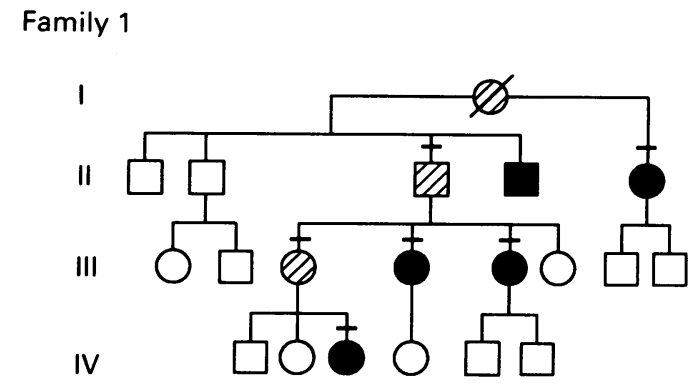

Figure 1 


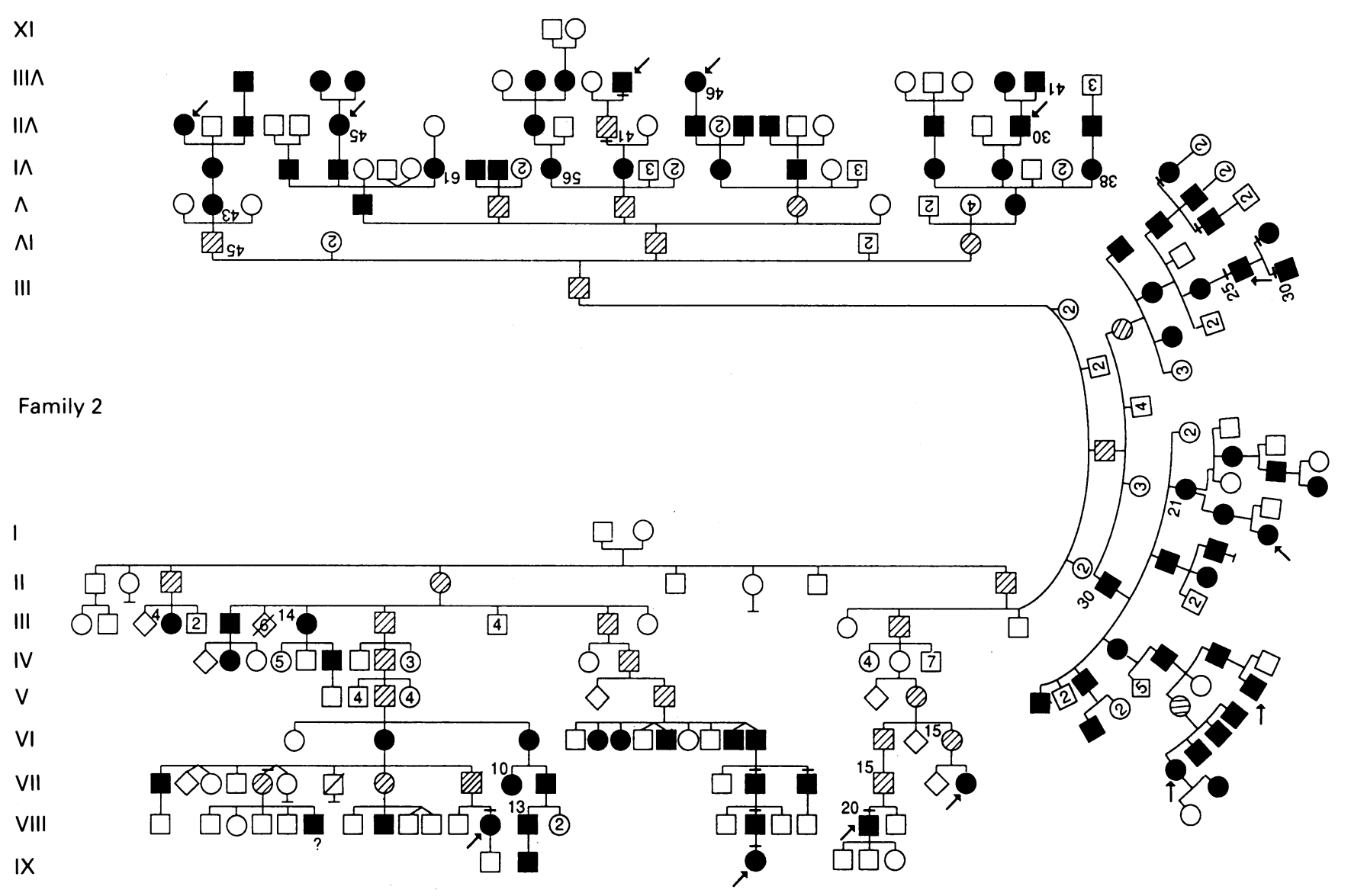

Family 3

Family 4

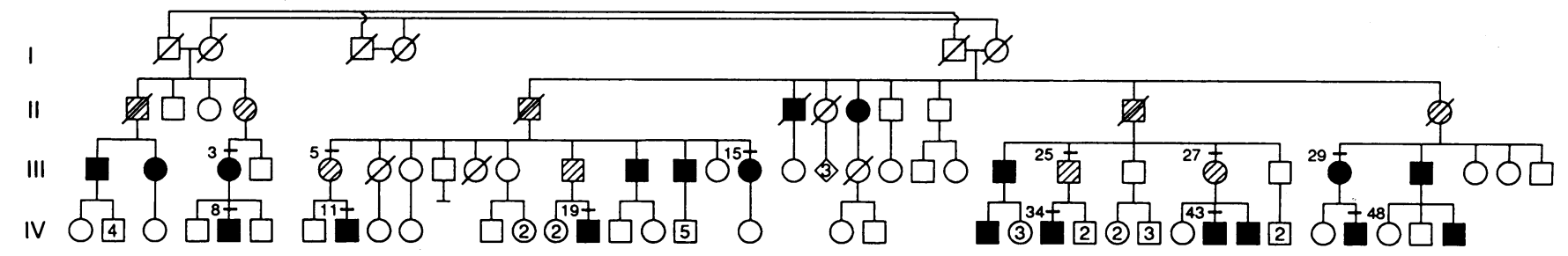

Figure 1 Pedigrees of families $1,2,3$, and 4. $\square$ : symptomatic individual; by the authors. 
Table 1 Age of onset of night blindness

\begin{tabular}{llllc}
\hline & \multicolumn{2}{l}{ Onset of night blindness } & & $\begin{array}{c}\text { No of patients } \\
\text { Eamily }\end{array}$ \\
\cline { 2 - 4 } & $<10$ years & $11-20$ years & $>21$ years & \\
\hline 1 & 4 & 0 & 0 & 4 \\
2 & 2 & 3 & 5 & 10 \\
3 & 2 & 0 & 0 & 2 \\
4 & 4 & 4 & 0 & $9^{\star}$ \\
\hline
\end{tabular}

^One patient denied any night blindness.

performed in accordance with the protocol described in Arden et $a l^{16}$ and the details of the method used for photopic flicker are given in Tyler et al. ${ }^{17}$ Dark adapted perimetry was performed on one eye (which showed least field loss on Goldmann perimetry) of each subject using red (dominant wavelength $660 \mathrm{~nm}$, subtending $0.9^{\circ}$ ) and green (dominant wavelength $530 \mathrm{~nm}$, subtending $0.9^{\circ}$ ) targets. The pupil was dilated with $1 \%$ cyclopentolate and the eye dark adapted for $\mathbf{4 0}$ minutes before starting the test. At least 17 points at different retinal locations in both upper and lower fields were tested in each case. The apparatus and method for the dark adapted static perimetry have been described previously. ${ }^{18}$

Symptomatic members from each family were screened for mutations in the rhodopsin and RDS genes. Exon sequences were amplified by the polymerase chain reaction using primers flanking the exons. ${ }^{919}$ Amplified fragments were run on hydrolink gels in order to detect mutations as heteroduplexed fragments of normal and mutated DNA sequences. ${ }^{21}$ This method has successfully detected 13 different mutations in the rhodopsin and RDS genes in 17 different families with retinal dystrophies ${ }^{1020}$ and appears to detect the same proportion of mutations in screening of RP families as single strand conformation polymorphism (SSCP) $)^{22}$ and denaturing gradient gel electrophoresis (DGGE). ${ }^{7}$

Linkage analysis was performed on markers

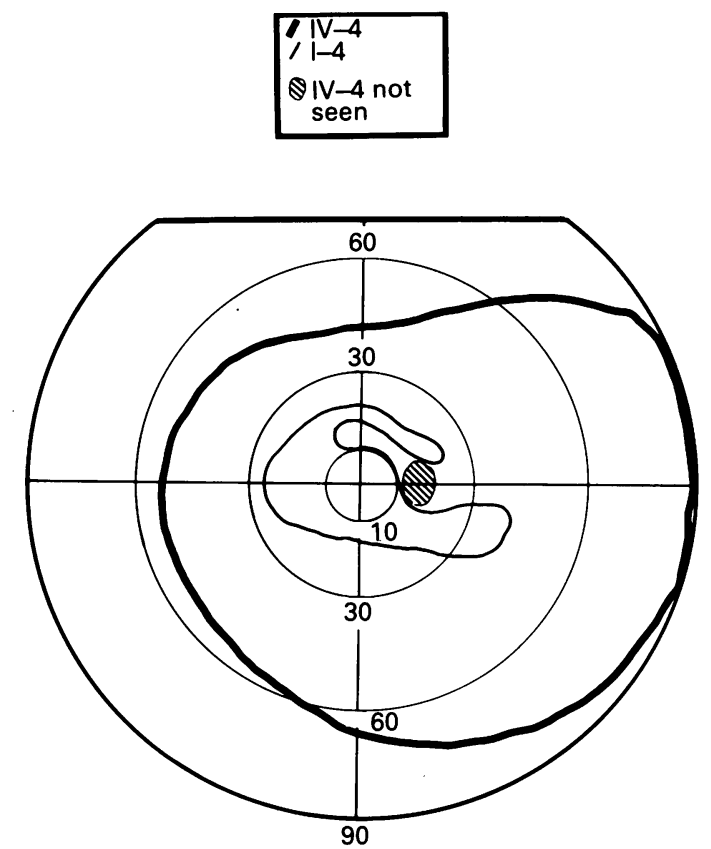

Figure 2 Goldmann field performed on the right eye of subject IV-34 from family 4.

within the rhodopsin and RDS genes in the families. The rhodopsin poly-CA tract $^{23}$ and the RDS gene poly-T tract ${ }^{24}$ were amplified by the polymerase chain reaction in symptomatic family members. One primer in each amplification was kinase end labelled with ${ }^{32} \mathrm{P}-\gamma$ ATP, then samples were run on denaturing acrylamide gels. The gels were dried and exposed to autoradiographic film overnight. Inheritance of alleles relative to the disease was analysed using the program LINKAGE, from the LINKAGE package version 5.10.25

Informed consent was obtained after the nature of the procedures had been fully explained.

Table 2 Affected patients: clinical findings

\begin{tabular}{|c|c|c|c|c|c|c|c|}
\hline Family & Subject & Age & $\begin{array}{l}\text { Acuity } \\
(R ; L)\end{array}$ & Cataract & Maculae & $\begin{array}{l}\text { Goldmann fields } \\
\text { (IV 4e target) }\end{array}$ & Electroretinogram \\
\hline $\begin{array}{l}1 \\
1 \\
1 \\
1 \\
2 \\
2 \\
2 \\
2 \\
2 \\
2 \\
2 \\
2 \\
2 \\
2 \\
2 \\
3 \\
3 \\
4 \\
4 \\
4 \\
4 \\
4 \\
4 \\
4 \\
4 \\
4\end{array}$ & $\begin{array}{l}\text { III-5 } \\
\text { IV-3 } \\
\text { III-4 } \\
\text { II-5 } \\
\text { VIII-12 } \\
\text { VIII-47 } \\
\text { VII-25 } \\
\text { VIII-30 } \\
\text { VIII-31 } \\
\text { VII-28 } \\
\text { VII-26 } \\
\text { VII-14 } \\
\text { VII-13 } \\
\text { VII-17 } \\
\text { IV-14 } \\
\text { V-2 } \\
\text { IV-11 } \\
\text { III-15 } \\
\text { IV-48 } \\
\text { IV-34 } \\
\text { IV-8 } \\
\text { III-3 } \\
\text { III-29 } \\
\text { III-19 } \\
\text { IV-43 }\end{array}$ & $\begin{array}{l}34 \\
18 \\
30 \\
42 \\
39 \\
13 \\
58 \\
19 \\
22 \\
33 \\
42 \\
46 \\
56 \\
24 \\
53 \\
22 \\
37 \\
45 \\
19 \\
16 \\
20 \\
45 \\
40 \\
18 \\
21\end{array}$ & $\begin{array}{l}6 / 18 ; 6 / 18 \\
6 / 18 ; 6 / 12 \\
6 / 36 ; 6 / 36 \\
6 / 18 ; 6 / 24 \\
6 / 12 ; 6 / 12 \\
6 / 5 ; 6 / 5 \\
6 / 36 ; \mathrm{NPL} \\
6 / 9 ; 6 / 9 \\
6 / 6 ; 6 / 6 \\
6 / 18 ; 6 / 12 \\
6 / 18 ; 6 / 18 \\
6 / 18 ; 6 / 18 \\
6 / 12 ; 6 / 12 \\
6 / 5 ; 6 / 5 \\
6 / 36 ; 6 / 36 \\
6 / 6 ; 6 / 5 \\
6 / 18 ; 6 / 18 \\
6 / 9 ; 6 / 9 \\
6 / 9 ; 6 / 6 \\
6 / 6 ; 6 / 6 \\
6 / 12 ; 6 / 12 \\
6 / 18 ; 6 / 9 \\
\text { LP;LP } \\
\text { LP†;6/5 } \\
\text { 6/6;6/6 }\end{array}$ & $\begin{array}{l}\text { Yes } \\
\text { No } \\
\text { Yes } \\
\text { Yes } \\
\text { Yes } \\
\text { No } \\
\text { Yes } \\
\text { No } \\
\text { No } \\
\text { Yes } \\
\text { Yes } \\
\text { Yes } \\
\text { No } \\
\text { No } \\
\text { Yes } \\
\text { No } \\
\text { Yes } \\
\text { Yes } \\
\text { No } \\
\text { No } \\
\text { Yes } \\
\text { Yes } \\
\text { Yes } \\
\text { No } \\
\text { No }\end{array}$ & $\begin{array}{l}\text { MO } \\
\text { MH } \\
\text { MA } \\
\text { MO } \\
\text { MO } \\
\text { Normal } \\
\text { MA } \\
\text { Normal } \\
\text { Normal } \\
\text { MO } \\
\text { MA } \\
\text { MO } \\
\text { MO } \\
\text { Normal } \\
\text { MA } \\
\text { Normal } \\
\text { MO } \\
\text { Normal } \\
\text { Normal } \\
\text { Normal } \\
\text { MO } \\
\text { MO } \\
\text { MA } \\
\text { Normal } \\
\text { Normal }\end{array}$ & 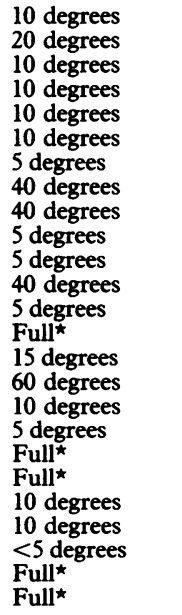 & $\begin{array}{l}\text { Non-recordable } \\
\text { Non-recordable } \\
\text { Non-recordable } \\
\text { Non-recordable } \\
\text { Not performed } \\
\text { Absent rod, minimal cone responses } \\
\text { Not performed } \\
\text { Rod and cone responses } \\
\text { Rod and cone responses } \\
\text { Non-recordable } \\
\text { Not performed } \\
\text { Absent rod, reduced cone responses } \\
\text { Non-recordable } \\
\text { Non-recordable } \\
\text { Non-recordable } \\
\text { Non-recordable } \\
\text { Non-recordable } \\
\text { Not performed } \\
\text { Absent rod, reduced cone responses } \\
\text { Absent rod, reduced cone responses } \\
\text { Non-recordable } \\
\text { Non-recordable } \\
\text { Not performed } \\
\text { Absent rod, reduced cone responses } \\
\text { Non-recordable }\end{array}$ \\
\hline
\end{tabular}




\section{Log elevation}

$>3.0 \bigcirc 0.6-1.0$

(1) $2.1-3.0 \quad 0 \leqslant 0.5$

1.1-2.0

(1)

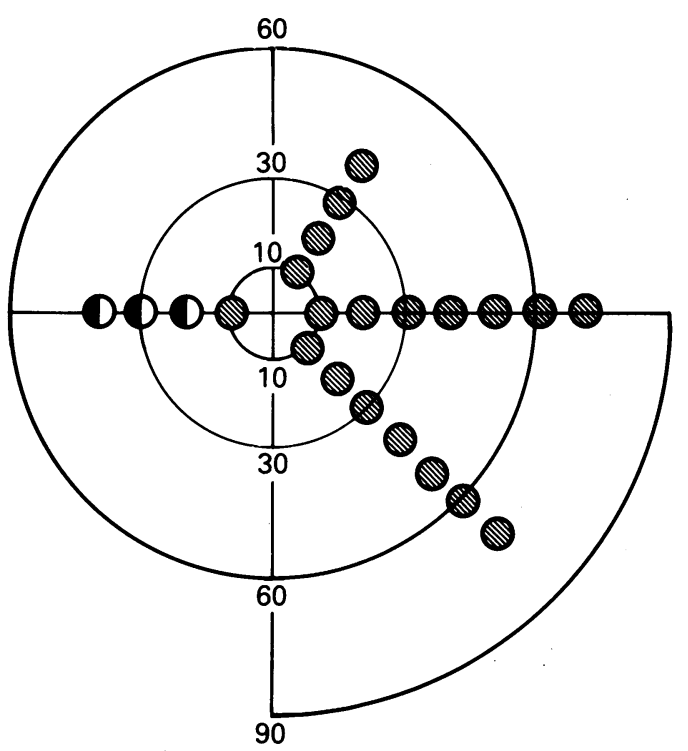

Figure 3 Static perimetry with red (dominant wavelength $660 \mathrm{~nm}$, subtending 0.9 degrees) target, performed on the dark adapted right eye of subject IV-34 from family 4 . The symbols represent the extent of threshold elevation relative to normal in log units. Visual angle in degrees is indicated on the vertical axis.

\section{Results}

\section{SYMPTOMATIC FAMILY MEMBERS}

\section{Clinical features}

In three families $(1,3,4)$ all symptomatic members had early onset of night blindness and evidence of severe disease. Of the 15 patients from these families 10 had onset of night blind-

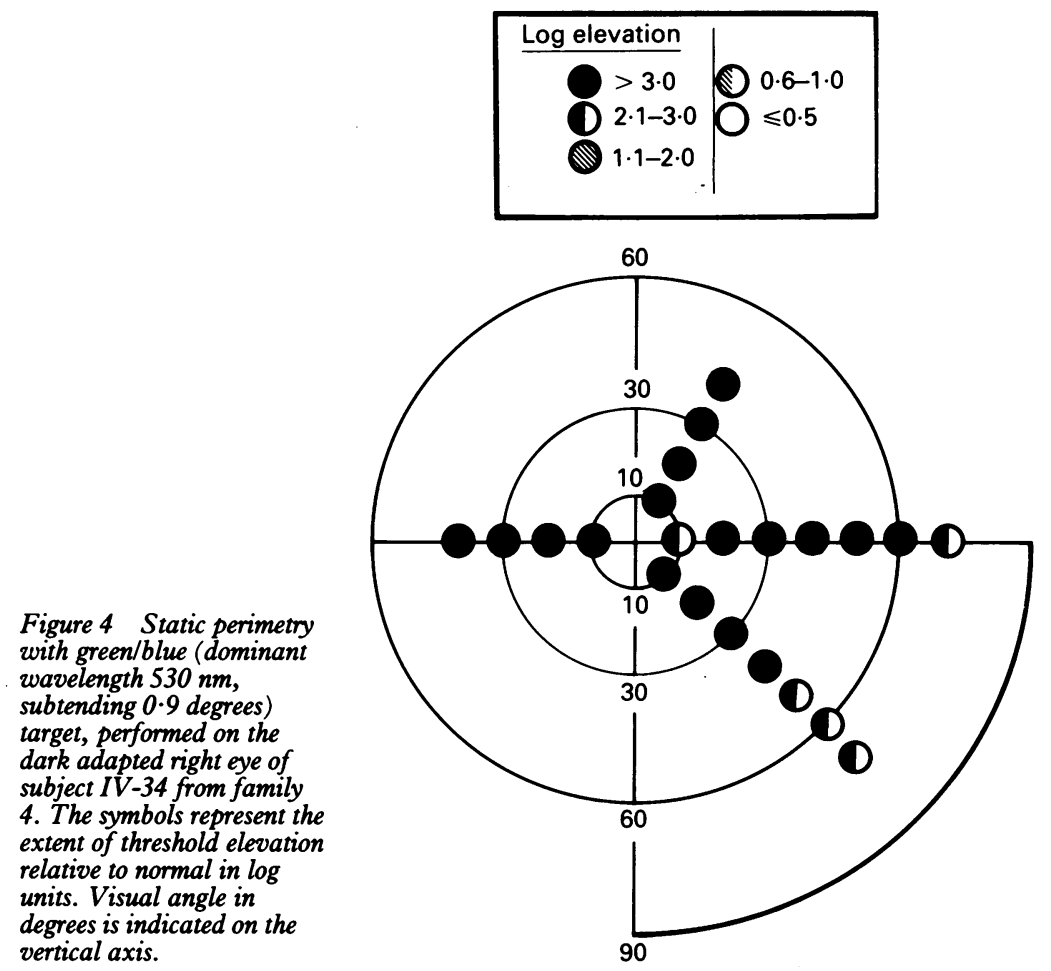

ness before the age of 10 years and in four the onset was before the age of 20 years. One denied symptoms of night blindness. In the fourth family (family 2 ) there was a more variable onset of symptoms with half the patients developing night blindness after the age of 20 years (Table 1). The results of the clinical examination are shown in Table 2 . In the majority of patients with reduced acuity, this was due to posterior subcapsular lens opacities or macular oedema or atrophy or a combination of these three factors. Macular oedema was present in 17 eyes, 26 of the 50 eyes had posterior subcapsular lens opacities, and one eye was aphakic. The typical fundus features of $\mathrm{RP}$ were seen in all 50 eyes.

Psychophysical testing and electroretinography Scotopic and photopic visual field testing showed extensive loss of rod and cone function in most subjects tested. Only one affected individual over the age of 25 had a visual field greater than 20 degrees to the larger target (IV 4e) of the Goldmann perimeter. Although field loss was greater with increasing age, severe field loss was also seen in young family members (Table 2). There were interfamilial and intrafamilial differences in severity. In family 1 all affected family members tested, including one 18 year old subject, had extensive field loss and this pattern of severe disease was also seen in family 4. Dark adapted static perimetry performed in four members of family 1 and eight members of family 4, similarly showed widespread elevation of rod and cone thresholds throughout the retina even in young family members (Figs 2, 3, 4).

The threshold elevations were such that classification into diffuse (type 1) or regional (type 2) disease $^{12}$ was not possible. In family 3 only one affected individual underwent dark adapted static perimetry and this again showed widespread and marked rod and cone threshold elevations. In these three families no subject had rod or cone thresholds within $1 \log$ unit of normal in any area of the visual field tested. In contrast, in family 2, there was more variation in the severity of disease. One 13 year old boy had visual fields, on Goldmann perimetry (IV $4 \mathrm{e}$ target) reduced to 10 degrees whereas other older symptomatic family members had well preserved fields to the same target (Table 2). Similarly scotopic perimetry showed widespread and severe rod and cone threshold elevations in some subjects while in others there were some areas of the visual field with normal or only mildly elevated rod and cone thresholds. In subjects with mild disease there was patchy loss of rod and cone function consistent with the regional pattern of disease described by Lyness et al. ${ }^{2}$

Electroretinography showed similar interfamilial variation (Table 2 ). In families 1,3 , and 4 there were no identifiable rod responses in any subject and most showed non-recordable cone responses. Two subjects from family 4 had delayed cone implicit times. In family 2 the ERG responses were consistent with the findings on psychophysical testing. Two subjects with mild disease showed well preserved rod and cone responses, and all subjects with recordable cone responses had normal cone $b$ wave implicit times. 

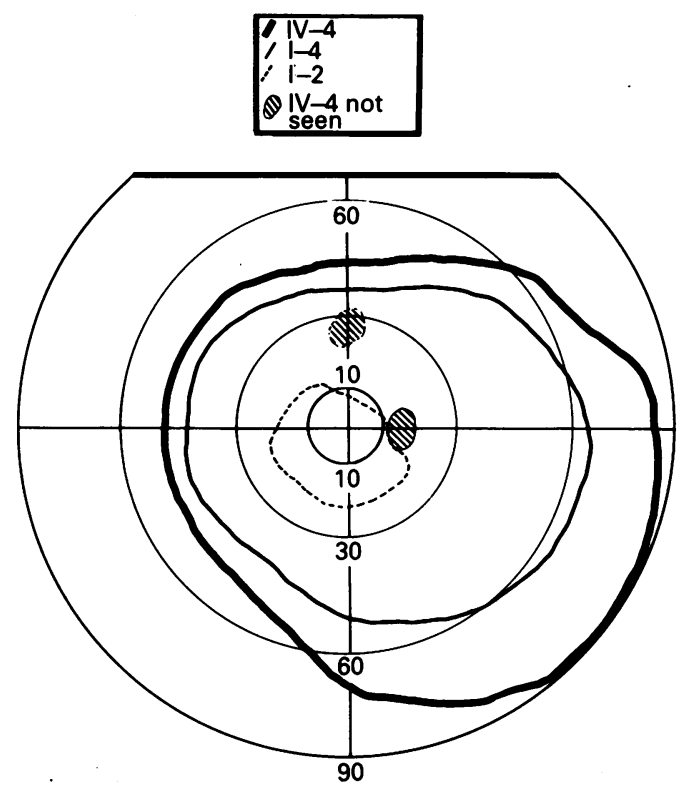

Figure 5 Goldmann field performed on the right eye of subject III-25 from family 4.

\section{ASYMPTOMATIC OBLIGATE GENE CARRIERS}

\section{Clinical findings}

All six subjects had normal visual acuity, normal fundus examination, and normal Goldmann fields to the larger target (IV 4e) used (Fig 5). Three subjects showed mild peripheral constriction and in two there were small mid peripheral scotomas to smaller targets (Table 3 ).

\section{Electrophysiological and psychophysical testing}

The light rise of the EOG showed a mild reduction in one or both eyes in three subjects (Table 3). The amplitudes of flash ERG were normal in five subjects and in one both scotopic and photopic responses were just below 2 SD from normal. Cone $b$ wave implicit times were prolonged in two subjects (Table 4). Dark adapted perimetry showed normal rod and cone responses at most of the retinal locations studied but in each subject there were mild rod threshold elevations (maximum threshold elevation 1.2$1.9 \mathrm{log}$ units) in at least one location. The results from a typical subject are shown in Figures 6 and 7, which can be compared with those of his 16 year old affected son (Figs 3 and 4). Flicker sensitivity was reduced in three subjects particularly at high frequencies (Table 4).

Table 3 Asymptomatic obligate gene carriers: results of perimetry, photopic flicker, and electro-oculography (EOG)

\begin{tabular}{|c|c|c|c|c|c|}
\hline Family & Subject & Age & Goldmann perimetry & $E O G(R / L)$ & Photopic flicker \\
\hline $\begin{array}{l}1 \\
1\end{array}$ & $\begin{array}{l}\text { II-3 } \\
\text { III-3 }\end{array}$ & $\begin{array}{l}60 \\
39\end{array}$ & \multirow{4}{*}{$\begin{array}{l}\text { Scotoma I-2e isoptre } \\
\text { Peripheral constriction } \\
\text { I-4e isoptre } \\
\text { Peripheral constriction } \\
\text { I-2e isoptre } \\
\text { Normal } \\
\text { Small scotoma I-4e } \\
\text { target } \\
\text { Peripheral constriction } \\
\text { I-2e target }\end{array}$} & $\begin{array}{l}241 / 161 \\
250 / 271\end{array}$ & \multirow{2}{*}{$\begin{array}{l}\text { Normal }^{\star} \\
\text { Relative high frequency } \\
\text { loss }>2 \text { SD } \\
\text { Normal }^{\star}\end{array}$} \\
\hline 2 & VII-41 & 40 & & $180 / 157$ & \\
\hline $\begin{array}{l}3 \\
4\end{array}$ & $\begin{array}{l}\text { IV-4 } \\
\text { III-25 }\end{array}$ & $\begin{array}{l}49 \\
41\end{array}$ & & $\begin{array}{l}258 / 235 \\
150 / 170\end{array}$ & \multirow{2}{*}{$\begin{array}{l}\text { Normal }{ }^{\star} \\
\text { Relative high frequency } \\
\text { loss }>2 \text { SD } \\
\text { Relative high frequency } \\
\text { loss }>2 \text { SD }\end{array}$} \\
\hline 4 & III-27 & 49 & & $200 / 218$ & \\
\hline
\end{tabular}

*Although photopic flicker was within $2 \mathrm{SD}$ of normal it was selectively reduced at the higher frequencies beyond 1 SD from normal.
MOLECULAR GENETICS OF THE FAMILIES

No mutations of the rhodopsin or RDS genes were found in any of the four families using the hydrolink heteroduplex method. In families 2, 3, and 4 crossovers occurred between intragenic markers within the rhodopsin gene and all four families showed crossovers with markers within the RDS gene, providing further evidence for the exclusion of these genes as the disease locus. Family 2 provided data excluding linkage (lod score $<-2 \cdot 0$ ) to rhodopsin and RDS at genetic distances of 3 and $4 \mathrm{cM}$ respectively. Families 3 and 4 proved less informative, but did show one and two crossovers respectively with the rhodopsin marker and two crossovers each with the RDS marker, significantly excluding the immediate genetic loci. Similarly, in family 1 one crossover was observed with the RDS marker; the rhodopsin polymorphism was uninformative in this family.

\section{Discussion}

In some autosomal dominant disorders individuals known to be carrying the abnormal gene, because of the presence of an affected offspring and parent, may show no evidence of the disease. This non-penetrance may be complete but often subtle signs of the disease may be apparent on careful examination and investigation or may develop with increasing age. The borderline between mild expression of a gene and nonpenetrance may therefore be difficult to define, especially in a disease such as adRP which may show a wide range of expression which is usually age dependent. Although non-penetrance has been described in adRP, there have been few

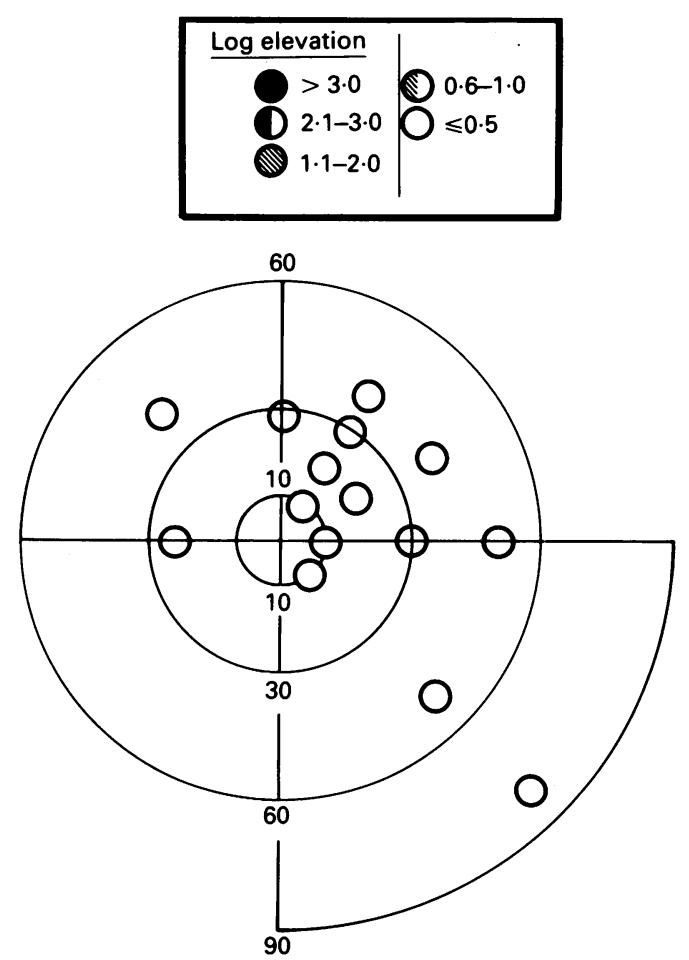

Figure 6 Static perimetry with red (dominant wavelength $660 \mathrm{~nm}$, subtending 0.9 degrees) target, performed on the dark adapted right eye of subject III-25 from family 4 . The symbols represent the extent of threshold elevation relative to normal in log units. Visual angle in degrees is indicated on the vertical axis. 


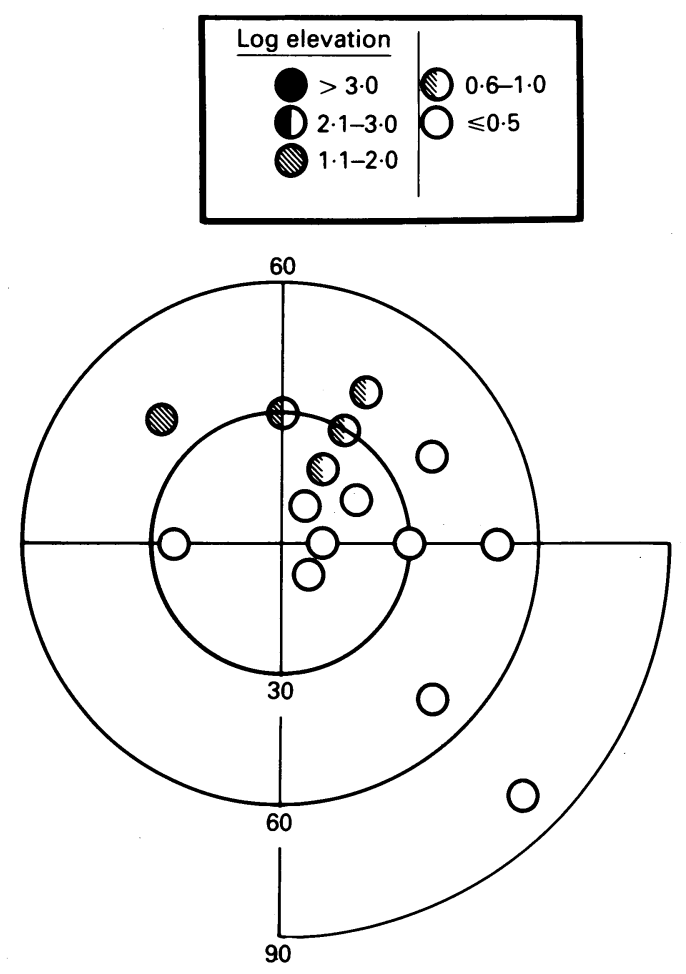

Figure 7 Static perimetry with green/blue (dominant wavelength $530 \mathrm{~nm}$, subtending 0.9 degrees) target, performed on the dark adapted right eye of subject III-25 from family 4. The symbols represent the extent of threshold elevation relative to normal in log units. Visual angle in degrees is indicated on the vertical axis.

systematic studies of such families. Berson $e t a l^{11}$ studied one family with incomplete penetrance and suggested on the basis of the electroretinographic findings that this was distinct from other forms of adRP showing complete penetrance. In their family and two others reported subsequently ${ }^{12}$ young symptomatic individuals showed substantially delayed cone implicit times. Two asymptomatic individuals age 42 and 75 years with the abnormal gene had a normal ERG and normal rod thresholds at the one location tested suggesting that they showed true non-penetrance of the gene. The younger patient tested 10 years later retained a normal full field ERG ${ }^{12}$ The families we have studied are similar to those reported by Berson and Simonoff ${ }^{12}$ in

Table 4 Asymptomatic obligate gene carriers: amplitude and implicit times of the flash ERG

\begin{tabular}{|c|c|c|c|c|c|c|c|c|c|c|}
\hline \multirow[b]{2}{*}{ Family } & \multirow{2}{*}{$\begin{array}{l}\text { Subject } \\
\text { eye }\end{array}$} & & \multicolumn{2}{|c|}{ Scotopic blue } & \multicolumn{4}{|c|}{ Bright flash white } & \multicolumn{2}{|c|}{ Flicker $(30 \mathrm{~Hz})$} \\
\hline & & & $b a m p$ & $b i m p$ & $a a m p$ & $a i m p$ & $b a m p$ & $b i m p$ & $b a m p$ & $b$ imp \\
\hline 1 & II-3 & \multirow{13}{*}{$\begin{array}{l}\mathbf{R} \\
\mathbf{L} \\
\mathbf{R} \\
\mathbf{L} \\
\mathbf{R} \\
\mathbf{L} \\
\mathbf{R} \\
\mathbf{L} \\
\mathbf{R} \\
\mathbf{L} \\
\mathbf{R} \\
\mathbf{L}\end{array}$} & 190 & 70 & 180 & 15 & 200 & 55 & 38 & 33 \\
\hline & & & 160 & 80 & 160 & 15 & 200 & 55 & 16 & 33 \\
\hline 1 & III-3 & & 270 & 60 & 160 & 15 & 260 & 55 & 32 & 31 \\
\hline & & & 250 & 60 & 120 & 15 & 360 & 55 & 32 & 31 \\
\hline 2 & VII-41 & & 60 & 60 & 120 & 16 & 80 & 50 & 30 & 35 \\
\hline & & & 50 & 60 & 120 & 16 & 80 & 50 & 30 & 35 \\
\hline 3 & IV -4 & & 260 & $\begin{array}{l}70 \\
68\end{array}$ & 140 & 15 & $\begin{array}{l}330 \\
360\end{array}$ & 50 & 35 & 31 \\
\hline 4 & III-25 & & $\begin{array}{l}225 \\
260\end{array}$ & $\begin{array}{l}68 \\
66\end{array}$ & $\begin{array}{l}140 \\
200\end{array}$ & $\begin{array}{l}16 \\
15\end{array}$ & $\begin{array}{l}360 \\
240\end{array}$ & $\begin{array}{l}52 \\
50\end{array}$ & $\begin{array}{l}40 \\
25\end{array}$ & $\begin{array}{l}31 \\
32\end{array}$ \\
\hline$T$ & & & 230 & 66 & 200 & 14 & 360 & 48 & 30 & 30 \\
\hline 4 & III-27 & & 180 & 60 & 240 & 15 & 240 & 50 & 25 & 32 \\
\hline & & & 140 & 60 & 200 & 15 & 360 & 48 & 30 & 30 \\
\hline \multirow{2}{*}{\multicolumn{2}{|c|}{$\begin{array}{l}\text { Normal mean } \\
\text { Normal }-2 \text { SD }\end{array}$}} & & 319 & 57 & 262 & 15 & 404 & 50 & 43 & 29 \\
\hline & & & 141 & 69 & 133 & 20 & 227 & 56 & 10 & 32 \\
\hline
\end{tabular}

$\mathbf{R}=$ right eye

a amp $=$ amplitude a wave in microvolts.

a imp=implicit time a wave in milliseconds.

a imp=implicit time a wave in milliseconds.

$b$ imp=implicit time $b$ wave in milliseconds. that some family members with the abnormal gene are asymptomatic and have a normal fundus appearance at an age when they would be expected to show clear signs of the disease. Although these 'skipped individuals' were normal on the basis of routine clinical testing, in contrast to the subjects reported by Berson $e t a l^{11}$ and Berson and Simonoff ${ }^{12}$ we have been able to show that all six subjects show mild electrophysiological or psychophysical abnormalities of retinal function in some retinal locations. The most consistent abnormality was elevated rod thresholds on dark adapted perimetry. The finding of abnormal cone implicit times on electroretinography and elevated photopic flicker thresholds in some subjects is consistent with the suggestion of Berson and Simonoff ${ }^{12}$ that there may be early peripheral cone involvement in this form of adRP.

In our families we have shown functional abnormalities in all members known to have the abnormal gene indicating that there is variable expression of the mutant gene rather than true non-penetrance. The question arises whether or not such families represent one or more distinct subtypes of adRP. On the basis of the findings in the asymptomatic obligate gene carriers they can be classified as type II or regional (R) type adRP ${ }^{12}$ but differ from other $\mathbf{R}$ type families we have studied both in the severity of disease seen in young symptomatic family members and in the wide range of disease severity. Although there is some interfamilial variability in the pedigrees reported here, they share many similarities, and it is possible that they may be caused by mutations at a single locus. Variations in the pattern of retinal dysfunction have been shown to be common with different mutations in the rhodopsin gene $^{26-32}$ and similar allelic heterogeneity may be seen in other genetic disorders. ${ }^{33}$ We have demonstrated that our families do not have mutations of the rhodopsin or RDS genes but this does not exclude the possibility that mutations of gene promoters or other related regulatory regions may be responsible. However, in three families we have excluded linkage to known loci on chromosomes 3 and 6 indicating that other genetic loci are involved. Whether or not such a wide range of expressions are caused by mutations at a single locus will depend upon the demonstration of the genetic defects.

One might expect families showing apparent incomplete penetrance to be those with mild disease of late onset, with the 'skipped individuals' being at the milder end of the disease spectrum. However, we have shown that symptomatic individuals have severe disease often of early onset. There must therefore be other factors, either genetic or environmental, that influence expression of the mutant gene. The extreme intrafamilial variation, with younger individuals often being severly affected, seen in our families make an environmental influence unlikely. Examination of the pedigree structure provides no evidence for anticipation ${ }^{34}$ or genomic imprinting effects ${ }^{35}$ and it seems more likely that other 'modifying' loci are responsible for influencing expression of the primary mutant gene. The identification of these genetic interactions remains a major challenge. 
This study was supported by the Medical Research Council (UK) The Wellcome Trust, British Retinitis Pigmentosa Society, and the National Retinitis Pigmentosa Society, Fighting Blindness, USA.

1 Massof RW, Finkelstein D. Two forms of autosomal dominan retinitis pigmentosa. Doc Ophthalmol 1981; 51: 289-346.

2 Lyness L, Ernst W, Quinlan MP, Clover GM, Arden GB Carter R, et al. A clinical, psychophysical, and electroretinographic survey of patients with autosomal dominant

3 Fishman GA, Alexander KR, Anderson RJ. Autosomal dominant retinitis pigmentosa: a method of classification. Arch Ophthalmol 1985; 103: 366-74.

4 Jacobson SG, Voigt WJ, Parel JM, Apathy PP, Nghiem-Phu $\mathrm{L}$, Myers SW, et al. Automated light and dark-adapted perimetry for evaluating retinitis pigmentosa. Ophthalmology 1986; 93: 1604-11.

5 Kemp CM, Faulkner DJ, Jacobson SG. Rhodopsin levels in autosomal dominant retinitis pigmentosa. Invest Ophthalmol Vis Sci 1988; 29: 1235-41.

6 Dryja TG, McGee TL, Reichel E, Hahn LB, Cowley GS, Yandell DW, et al. A point mutation of the rhodopsin gene in one form of retinitis pigmentosa. Nature 1990; 343: 364-6.

7 Sung CH, Davenport CM, Hennessey JC, Maumenee IH, Jacobsen SG, Heckenlively JR, et al. Rhodopsin mutations in autosomal dominant retinitis pigmentosa. Proc Natl Acad Sci 1991; 88: 6481-5.

8 Farrar GJ, Jordan SA, Kenna P, Kumar-Singh R, Humphries HM, Sharp EM, et al. A three base pair deletion in the peripherin-RDS gene in one form of retinitis pigmentosa. Nature 1991; 354: 478-80.

9 Kajiwara K, Hahn LB, Mukai S, Travis GH, Berson EL, Dryja TP, et al. Mutations in the human retinal degeneration slow gene in autosomal dominant retinitis pigmentosa. Nature 1991; 354: 480-3.

10 Wells J, Wrobleweski J, Keen J, Inglehearn C, Jubb C, Eckstein A, et al. Mutations in the human retinal degeneration slow (RDS) gene can cause either retinitis pigmentosa or ton slow (RDS) gene can cause either retinitis pig

11 Berson EL, Gouras P, Gunkel RD, Myrianthopoulos NC. Dominant retinitis pigmentosa with reduced penetrance. Dominant retinitis pigmentosa with

12 Berson EL, Simonoff EA. Dominant retinitis pigmentosa with reduced penetrance. Further studies of the electroretinogram. Arch Ophthalmol 1979; 97: 1286-91.

13 Moore AT, Ernst W, Jay M, Arden GB, Bird AC. Autosomal dominant retinitis pigmentosa with apparent incomple penetrance. Invest Ophthalmol Vis Sci 1987; 28 (Suppl): 112

14 Ernst W, Moore AT. Heterogeneity, anomalous adaption and incomplete penetrance in autosomal dominant retinitis pigmentosa. Adv Biosci 1987; 62: 115-20.

15 Jay M, Jay B, Moore AT, Bird AC. Nine generations of a family with autosomal dominant retinitis pigmentosa and family with autosomal dominant retinitis pigmentosa and evidence of variable expressivi

16 Arden GB, Carter RM, Hogg CR, Powell DJ, Ernst WJK, Clover CM, et al. A modified ERG technique and the results obtained in X linked retinitis pigmentosa. Brf Ophthalmol 1983; 67: 419-30

17 Tyler CW, Ernst W, Lyness AL. Photopic flicker losses in simplex and multiplex retinitis pigmentosa. Invest Ophthalmol Vis Sci 1984; 25: 1035-42.

Note added on proof:

Since acceptance of this paper the disease locus in family 2 has been identified on chromosome $7 p$ (Inglehearn CF, Carter SA, Keen TJ, Lindsey J, Stephenson AM, Bashir R, et al. A new locus for autosomal dominant retinitis pigmentosa (adRP) on chromosome $7 \mathrm{p}$. Nature Genetics 1993, in press).
18 Ernst W, Faulkner DJ, Hogg CR, Powell DG, Arden GB, Vaegen. An automated static perimeter/adaptometer usin light emitting diodes. $\mathrm{Br} \mathcal{F}$ Ophthalmol 1983; 67: 431-42. 19 Travis GH, Christerson L, Danielson PE, Klisak I, Sparkes RS, Hahn LB, et al. The human retinal degeneration slow (RDS) gene: chromosome assignment and structure of the mRNA. Genomics 1991; 10: 733-9.

20 Inglehearn CF, Keen TJ, Bashir R, Jay M, Fitzke F, Bird AC, et al. A completed screen for mutations of the rhodopsin gene in a panel of patients with autosomal dominant retinitis pigmentosa. Hum Mol Genet 1992; 1: 41-5.

21 Keen TJ, Lester D, Inglehearn CF, Curtis A, Bhattachary SS. Rapid detection of single base mismatches as heteroduplexes on hydrolink gels. Trends in Genetics 1991; 7: 5 . 22 Dryja TP, Hahn LB, Cowley GS, McGee TL, Berson EL. Mutation spectrum of the rhodopsin gene among patients Mutation spectrum of the rhodopsin gene among patients with autosomal dominant retinitis

23 Weber JL, May PE. Abundant class of human DNA polymorphisms which can be typed using the polymerase chain reaction. Am f Hum Genet 1989; 44: 388-96.

24 Kumar-Singh R, Jordan SA, Farrar GJ, Humphries P. Poly T/A) polymorphism at the human retinal degeneration slow RDS) locus. Nucl Acids Res 1992; 19: 5800.

25 Lathrop GM, Lalouel JM, Julier C, Ott J. Strategies for multipoint linkage analysis in humans. Natl Acad Sci USA 1984; 81: 3443-6.

26 Heckenlively JR, Rodrigues JA, Daiger SP. Autosomal dominant sectoral retinitis pigmentosa, two families with transverse mutations in codon 23 or rhodopsin. Arch Ophthalmol 1991; 109: 84-91.

27 Berson EL, Rosner B, Sandberg MA, Dryja TP. Ocular findings in autosomal dominant retinitis pigmentosa and rhodopsin gene defect. Arch Ophthalmol 1991; 109: 92-101.

28 Weleber RG, Murphey WH, Rodrigues JA, Lourien EW, Lit M, Daiger SP. Phenotypic expression of the Pro23His mutation of rhodopsin in a large family with autosomal dominant retinitis pigmentosa. Invest Ophthalmol Vis $S c$ 1991; 32 (Suppl): 913.

29 Fishman GA, Stone EM, Gilbert LD, Kenna P, Sheffield VC. Ocular findings associated with a rhodopsin gene transversion mutation in autosomal dominant retinitis pigmentosa. Arch Ophthalmol 1991; 109: 1387-93.

30 Jacobson JG, Kemp CM, Sung CH, Nathans J. Retinal function and rhodopsin levels in autosomal dominant retinitis pigmentosa with rhodopsin mutations. Am 7 Ophthalmol 1991; 112: 256-71.

31 Kemp CM, Jacobson JG, Roman AJ, Sung CH, Nathans J. Abnormal rod adaptation in autosomal dominant retinitis pigmentosa with Pro-23-His rhodopsin mutation Am F Ophthalmol 1992; 113: 165-74.

32 Moore AT, Fitzke FW, Kemp CM, Arden GB, Keen TI, Inglehearn CF, et al. Abnormal dark adaptation kinetics in Inglehearn CF, et al. Abnormal dark adaptation kinetics in opsin mutation. Br 7 Ophthalmol 1992; 76: 465-9.

33 Suthers GK, Davies KE. Phenotypic heterogeneity and the single gene [Editorial]. Am f Hum Genet 1992; 50: 887-9]. 34 Harper PS, Harley HG, Reardon W, Shaw DJ. Anticipation in myotonic dystrophy: new light on an old problem. Am $\mathcal{F} M e d$ Genet 1992; 51: 10-16.

35 Moore T, Haig D. Genomic imprinting in mammalian development: a parental tug of war. Trends in Genetics 1991 7: 45-9. 